Bull. Fac. Agric., Cairo Univ., 67: 193 -212 (2016).

\title{
APPLICATION OF ACUTE PHASE PROTEINS (APPs) AS BIOMARKERS IN CHICKENS: A REVIEW
}

(Received: 8.8.2016)

\author{
By \\ A. M. Al-Dawood \\ Department of Applied Biology, College of Sciences, Tafila Technical University, Tafila, Jordan
}

\begin{abstract}
The importance of poultry industry to the world' economy is increasing. The current methods for identifying chickens' health problems are traditional and looking for new tools to diagnose poultry problems is of vital importance. Poultry industry is affected by infectious and metabolic disorders which are common in chickens and affect their well-being, cause stress, reduce performance and increase mortality. Measuring the acute phase proteins; secreted from the liver as a result of inflammation and/or infection that can be measured in plasma; levels were found to be useful in assessment of health status and prediction of diseases of the animals, and useful markers of inflammation in veterinary clinical pathology. Thus, acute phase proteins as diagnostic markers may be of a great value in identifying chickens' health problems, and thereby should allow optimal and fast measures to improve chickens' health and welfare. Although a wide range of studies has been carried out to determine the usefulness of acute phase proteins in several diseases in ruminants, their use as indicators in detection of diseases in chickens is less well documented. For this reason, this review article deals with the role of acute phase proteins in chickens' welfare, and brings together the studies on acute phase proteins that have been undertaken in chickens. In this review article, the immune system, acute phase response and the general diagnostic utility of acute phase proteins in veterinary practice were given. In addition, the most important acute phase proteins in chickens and their diagnostic utility in relation to metabolic disorders, inflammation, common chickens' diseases and stress were thoroughly discussed. Finally, this review highlights research gaps and directions deserving further development to create a better understanding of acute phase proteins for making these biomarkers a perfect predictive tool for chickens' health status and valuable diagnostic approaches in chickens.
\end{abstract}

Key words: Acute phase proteins, chickens, biomarkers, animal health, diagnosis, inflammation, management.

\section{INTRODUCTION}

The importance of poultry industry to the world' economy is increasing. Chicken eggs and meat represent good and cheap protein sources compared to beef or mutton. In addition, short productive lifespan, eggs production, dietary restrictions' absence and worldwide distribution, all favor the use of poultry as a major source of animal protein (Davison et al., 2008). Infectious and metabolic disorders, stress and stressful conditions are common in poultry and adversely affect behavior, production and physiology (Virden and Kidd, 2009).

Animal body reacts to all kinds of injuries and stressors to keep homeostasis. Resistance can be specific or nonspecific. Nonspecific innate resistance of the body, i.e. cytological and cytokine reactions are known as acute phase response. Thus, acute phase response is a nonspecific and complex reaction of an organism, triggered by different stimuli, i.e. injury, trauma, infection, inflammation, stress, neoplasia or tissue damage (Ceron et al., 2005; Gruys et al., 2006; Cray et al., 2009). Acute phase response comprises a wide variety of behavioral, physiological, biochemical and nutritional changes.

The acute phase proteins are blood proteins primarily synthesized by hepatocytes as a part of the acute phase response (Tothova et al., 2014). The most important metabolic change during the acute phase response includes the increased or decreased production of acute phase proteins 
from the liver (Ceciliani et al., 2002; Murata et al., 2004). Measuring the acute phase proteins' levels is found to be useful in assessment of health status and prediction of diseases of the animals, and also useful markers of inflammation in veterinary clinical pathology (Cray et al., 2009). Changes in many acute phase proteins are well observed in the early stages of infections in many animal species. This has led to the utilization of acute phase proteins by clinicians as a reliable sign for the presence of any form of inflammation (Kaneko, 1997).

Infectious and metabolic disorders are common in chickens and affect well-being, cause stress, reduce performance and increase mortality. Although pathogens such as bacteria, viruses and parasites cause inflammation and infection, metabolic problems in chickens are also related to management and environmental challenges (Rath et al., 2009). Thus, acute phase proteins as diagnostic markers may be of great value in identifying chickens health problems, and thereby should allow optimal and fast measures to improve chickens' health and welfare (Eckersall, 2004; Rath et al., 2009). Nevertheless, acute phase proteins have been identified in many animal species including chickens, and have been used to assess their health status (Eckersall, 2004; Murata et al., 2004; Petersen et al., 2004; Gruys et al., 2006; Firouzi et al., 2014). The acute phase proteins are found to be more sensitive and specific than the routine diagnostic methods. Nevertheless, the use of acute phase proteins as biomarkers for animal disease diagnosis and health status assessment has got high potential in modern veterinary practice (Pradeep, 2014).

\section{IMMUNE SYSTEM}

Birds have many immunological mechanisms in common with mammals but have evolved a number of quite distinct strategies; they achieve the same goal through the use of different mechanisms (Davison et al., 2008). However, the immune system is classified into innate and adaptive immunity, which are highly interactive and coordinated to provide an optimal resistance to infectious diseases (Lippolis, 2008). The innate immune response is the first and fastacting line of host defense against the invading pathogens, which serves to initiate the acquired immune response, and this response can be localized within affected tissues or mobilized to the site of infection (Helle et al., 2008). The innate immune system is very diverse and prevents infection, eliminates potential pathogens, and initiates the inflammatory process (Janeway et al., 2001). Components of the innate defense include the physical barrier of the skin and mucous epithelia, leukocytes (macrophages, neutrophils and natural killer cells), non-immune cells (epithelial and endothelial cells), and certain soluble mediators (cytokines, eicosanoids and acute phase proteins) (Helle et al., 2008; Sordillo et al., 2009). Inflammation is one of the hallmarks and first responses of the innate immune system to infection, and is associated with heat, redness, pain, swelling and impaired function. The innate immune system has two main functions: removing the injurious agents and initiating the tissue healing process (Lippolis, 2008; Sordillo et al., 2009). However, the innate immunity is expressed in a variety of guises, from the initial response to physical and chemical attack by invading microorganisms to the coordinated recruitment and action of a series of specialized cell populations (Helle et al., 2008). There are innate mechanisms that operate as a constitutive barrier function, including the nature of epithelial surfaces and the molecules that coat them, such as mucus and antimicrobial chemical components. There are also inducible biochemical responses, including alterations in mucus composition and increased secretion of constitutive components, and production of antimicrobial compounds (Davison et al., 2008). The innate responses are considered important in the earliest phases of microbial invasion, limiting the spread of the pathogen until adaptive responses become mobilized to clear the infection (Davison et al., 2008).

\section{Acute phase response and acute phase proteins}

\subsection{Acute phase response}

Animal body shows two types of immune reaction to any type of injury as discussed before. One is the specific immune reaction mediated by antibodies and the other is the innate nonspecific immune reaction like fever and cytological reactions. This innate nonspecific immune reaction of the body is known as acute phase response (Pradeep, 2014). The acute phase response is the first line of defense that many vertebrates employ during a pathogenic challenge (Owen-Ashley and Wingfield, 2007). The acute phase response represents a group of physiological processes occurring soon after the onset of infection, tissue injury, trauma, inflammation, stress and 
neoplastic growth or immunological disorders (Cray et al., 2009; Tothova et al., 2014). This response is composed of physiological, behavioral, hormonal and metabolic changes that include fever, iron sequestration, anorexia, adipsia, activation of the hypothalamopituitaryadrenal axis and suppression of the hypothalamopituitary-gonadal axis (OwenAshley and Wingfield, 2007; Ceciliani et al., 2012). The aim of these changes is to isolate and destroy the infectious agent, restore homeostasis and promote the resolution and the healing process (Cray et al., 2009; Pradeep, 2014).

The acute phase response begins within inflammatory sites, where cells involved in the innate immune response such as macrophages and monocytes that produce and release a number of inflammatory mediators, among which the cytokines (i.e., interleukin-1, interleukin- 6 and tumor necrosis factor- $\alpha$ play a significant role (Bochsler and Slauson, 2002). These cytokines influence organs involved in homeostasis such as the central nervous system, the autonomic nervous system and the adrenal gland to establish a rapid and intense protective or reactive response (Moshage, 1997). Cytokines induce a cascade of events which potentiate the appearance of characteristic clinical changes such as fever, anorexia or weight loss (Gabay and Kushner, 1999). In addition, cytokines activate receptors on different target cells leading to systemic inflammatory reactions, including hormonal or metabolic, resulting in a number of biochemical changes, such as increased production of adrenocorticotrophic hormone and glucocorticoids, activation of the blood coagulation system, and changes in the levels of some plasma proteins (Gruys et al., 2005). Cytokines, therefore, act like mediators between the local site of injury and the hepatocytes (liver) to produce and release the acute phase proteins (Jain et al., 2011). Nonetheless, the acute phase response is broadly effective at controlling infection (Blatteis, 2006), and may be favored in circumstances where rapid response to infection is required or when rapid development precludes investment in adaptive immunity (Klasing, 2004). The proinflammatory cytokines are responsible for the induction of the mentioned fever and muscle catabolism, and they activate white blood cell precursors in the bone marrow, growth of inflammatory tissue fibroblasts and macrophages (van Miert, 1995). It is important to realize that the acute phase protein-response-inducing cytokines represent small molecules with very short half-life. Therefore, cytokines are not very useful for most general diagnostic purposes in contrast to the acute phase proteins (Gruys et al., 1994).

\subsection{Acute phase proteins}

The acute phase proteins are a large group of plasma proteins, which are released into the blood stream in response to a variety of stressors (Tothova et al., 2014). Acute phase proteins are proteins whose plasma levels increase or decrease, after a specific stimulus, classifying them into positive (e.g. C-reactive protein, serum amyloid A, haptoglobin), and negative (e.g. Albumin) acute phase proteins, respectively (Jain et al., 2011; Gómez-Laguna et al., 2011). Acute phase proteins are further classified as major, moderate or minor depending on their levels. Major acute phase proteins may show up to 10 - to 1000-fold increase in its serum level in 1-2 days; moderate acute phase proteins display 4- to 10-fold increase in 2-3 days; and minor acute phase proteins represent those with only slight, 2- to 3-fold increases (Ceron et al., 2005; O'Reilly and Eckersall, 2014). Major acute phase proteins are often observed to increase markedly within 24-48h after the triggering event and often exhibit a rapid decline due to their very short half-life (Jain et al., 2011). Moderate and minor acute phase proteins tend to increase more slowly, peak at 2-3 days and have more prolonged duration (Niewold et al., 2003; Eckersall and Bell, 2010).

The acute phase proteins play an important role in various stages of the inflammatory reaction (Tothova et al., 2014). The main functions of acute phase proteins are to defend the host against pathological damage, assist in the restoration of homeostasis and regulate the different stages of inflammation (Petersen et al., 2004). In addition, acute phase proteins have a number of antimicrobial properties such as opsonization of bacteria, activation of complement, enhancement of phagocytosis and scavenging of minerals from the bloodstream that are limiting for bacterial growth and replication (Baumann and Gauldie, 1994). Furthermore, some of the acute phase proteins have anti-protease activity designed to inhibit proteases released by phagocytes or pathogens to minimize damage to normal tissues (Tothova $e t$ al., 2014). Other acute phase proteins have scavenging activities and bind metabolites released from cellular degradation (Wagener $e t$ al., 2001). More others are characterized by anti- 
bacterial activity and the ability to influence the course of the immune response (Fournier et al., 2000).

Most acute phase proteins are synthesized in the liver upon stimulation with pro-inflammatory cytokines and glucocorticoids, and subsequently released into the blood stream. The main proinflammatory cytokines involved are interleukin6 , interleukin-1 and tumor necrosis factor- $\alpha$. These cytokines are produced by tissue macrophages and peripheral blood monocytes, the most likely cells to initiate the acute phase response as they become activated upon encounter with foreign organisms (Hiss et al., 2008). Over a period of $12-24 \mathrm{~h}$ the liver responds to the cytokine exposure and starts to produce the positive acute phase proteins and decrease the production of the negative acute phase proteins. Thus, liver is the main target for the production of acute phase proteins, especially the hepatocytes; however, several extrahepatic sites have been reported (Hiss et al., 2008).

\section{The diagnostic utility of acute phase proteins in veterinary practice}

The use of acute phase proteins has gained importance in veterinary medicine in the mid1990s (Pradeep, 2014). Acute phase proteins are usually used in veterinary medicine, i.e. checking the health status of animals, indicating how intense or serious the inflammation is, monitoring inflammatory activity during the course of treatment and efficacy of treatment at the earliest by detecting a decrease in acute phase proteins' levels; and helping in antemortem inspections of large herds in slaughter houses (Pradeep, 2014). However, the use of acute phase proteins in diagnosis and their applications in monitoring of treatments are considered as one of the most interesting applications of acute phase proteins (Tothova $e t$ al., 2014). A significant progress has been made in the detection, measurement and application of acute phase proteins as biomarkers in farm animals over recent years.

The monitoring of two or more acute phase proteins is highly valuable in different diseases as each acute phase protein may display a different kinetic after the infection/trauma in the animal (Eckersall, 2000). This information may be of interest to evaluate the progress of the disease and may help in the prognosis of animals' health. Moreover, acute phase proteins' changes reflect the presence and intensity of inflammation, and they have long been used as a clinical guide for diagnosis (Chamanza et al., 1999a, b). Nevertheless, acute phase proteins are recognized as promising tools to assess welfare, health and performance in animal production (Petersen et al., 2004). Acute phase proteins have very high sensitivity in detecting many conditions that alter the health of the animal (Ceron et al., 2005), and they quickly and precisely demonstrate the presence of infectious and inflammatory conditions (Petersen et al., 2004), but not the cause (Kent, 1992). It has been suggested that a single acute phase protein should not be exclusively used to monitor a disease process. Instead, an acute phase protein index has been used in veterinary medicine (Gruys et al., 2006). This index includes both positive acute phase proteins (their levels are increased many fold) and negative acute phase proteins (their levels are decreased), and acute phase proteins that increase rapidly (increase markedly within $24-48 \mathrm{~h}$ after the triggering event) and slowly (increase more slowly), thereby forming a comprehensive index that would correlate with the severity of the inflammatory process.

\section{Acute phase proteins in chickens and their diagnostic utility}

The chickens acute phase proteins are much less characterized as compared to ruminants' acute phase proteins, although in the past years many studies have been published on chickens acute phase proteins' changes in association with inflammation, infection and common chickens' diseases (Hallquist and Klasing, 1994; Tohjo et al., 1995; Nakamura et al., 1998; Takahashi et al., 1998; Chamanza et al., 1999a, b; Barnes et al., 2002; Nazifi et al., 2010). Measuring plasma levels of acute phase proteins could be useful for monitoring chickens' health (Tohjo et al., 1995), and identifying inaccessible lesions at meat inspection (Saini and Webert, 1991). It is essential for chickens' veterinarian to determine the chronicity, severity and resolution of lesions, especially for broilers in the last few weeks before slaughter when drug withdrawal times have to be observed. In addition, measuring acute phase protein levels may complement post-mortem findings in determining chickens health.

Infectious and metabolic disorders are common in chickens and cause stress, poor performance and mortality that result in considerable economic loss. Identifying the nature of stress in chickens will assist the development of appropriate measures to improve 
health and welfare (Rath et al., 2009). Thus, acute phase proteins are used as nonspecific diagnostic markers for various health disorders. The possible use of acute phase proteins in chickens has been investigated in various inflammatory and non-inflammatory conditions, and in experimental infections and natural diseases (specific bacterial, viral or parasitic infections) which provide data for veterinarians and producers regarding the possible use of acute phase proteins as biomarkers of diseases in chickens (Table 1). In chickens, many acute phase proteins have been described so far, of theses serum amyloid A, C-reactive protein, haptoglobin, ceruloplasmin, transferrin, ovotransferrin, fibrinogen, alpha-1-acid glycoprotein, albumin, mannan-binding lectin, fibronectin and hemopexin (Amrani et al., 1986; Grieninger et al., 1986; Hallquist and Klasing, 1994; Tohjo et al., 1995; Inoue et al., 1997; Chamanza et al., 1999a; Nielsen et al., 1998a, b; Holt and Gast, 2002).

\subsection{Serum Amyloid A}

The serum Amyloid A is an apolipoprotein of the high-density lipoprotein fraction of plasma (Uhlar et al., 1994). It is constitutively expressed at different levels in response to inflammatory stimuli (Jensen and Whitehead, 1998). During inflammation, serum amyloid A is mainly expressed in the liver, and it is also induced in many distinct tissues such as mammary gland (Weber et al., 2006). Serum amyloid A carries out several functions related to the inflammatory responses such as cholesterol removal from the local site of inflammation and transport to hepatocytes; chemotaxis of monocytes, polymorphonuclear leukocytes and $\mathrm{T}$ cells; inhibitory effect on fever, oxidative burst and platelet activation (Ceciliani et al., 2002; and Petersen et al., 2004). This protein stimulates the production of mucin from intestinal cells, and thus helps to prevent bacterial colonization (Mack et al., 2003). Serum amyloid A shows more than 100-fold increase after any injury, which triggers off the acute phase response (Petersen et al., 2004).

Salmonella gallinarum infection is one of the most important infectious poultry diseases, causing high death rate and economical losses (Shivaprasad, 1997). In addition, bacterial infection of the navel and yolk sac retention of newly hatched chicks is an economically important disease which caused by Escherichia coli, Staphylococcus aureus and/or Aspergillus fumigatus (Khan et al., 2004). In chickens, serum amyloid $\mathrm{A}$ is a major positive acute phase protein increasing 10 - to 100 -fold upon stimulation with $E$. coli or $S$. aureus (Chamanza et al., 1999a; Upragarin, 2005). In birds, persistently elevated serum amyloid A levels, together with ongoing inflammatory and/or infectious disease may result in the formation of AA amyloid protein. The accumulation of this proteinaceous serum amyloid A derivative in organs and tissues gives rise to the disease AA amyloidosis (Röcken and Shakespeare, 2002). In chickens industry, there is an increasing interest in serum amyloid A since amyloid arthropathy is a major problem in layer hens (Chamanza et al., 1999a). Serum amyloid A level was significantly higher in non-vaccinated challenged birds compared with vaccinated challenged ones in chickens (Firouzi et al., 2014). In addition, serum amyloid $\mathrm{A}$ is useful acute phase protein for detecting acute lesions in chickens (Chamanza et al., 1999a). Levels of serum amyloid A were higher in diseased birds with ulcerative enteritis (Nazifi et al., 2011b), and infectious bronchitis virus (Asasi et al., 2013). In addition, significant increase in serum amyloid A level in Gumboro virus-infected chicks (Nazifi et al., 2010) and retained yolk sac infected chicks has been reported (Mosleh et al., 2012). Serum amyloid A was not detected in healthy chickens but was detected in turpentineinjected pullets and in S. aureus-infected broilers (Chamanza et al., 1999a). Upragarin (2005) found that serum amyloid A increased as a result of turpentine and $S$. aureus injection with serum amyloid A levels increasing from undetectable levels pre-injection to increases of 100-1000 fold 12 hours post injection. Alasonyalilar et al. (2006) found severely amyloidotic birds to have mean serum amyloid A level much higher than control levels. Thus, data suggest that serum amyloid A could be a useful marker for prognosis and diagnosis of important diseases in chickens. Nevertheless, it is important to mention that in chronic stages of diseases, serum amyloid A should be measured in combination with other acute phase proteins such as alpha-1acid glycoprotein and transferrin (Chamanza et al., 1999a).

\subsection{C-Reactive protein}

This acute phase protein plays an important role in the protection against infection, clearance of damaged tissue, prevention of autoimmunity and regulation of the inflammatory response (Helle et al., 2008). The C-reactive protein was the first acute phase protein to be recognized 
(Abernethy and Avery, 1941), which in man has become the most important analyte providing diagnostic information on the presence of inflammatory lesions, and the response to treatment (Gabay and Kushner, 1999). Some researchers consider C-reactive protein as a useful tool to differentiate between bacterial or viral infection, while some others could not detect such differences because of the individual variability. C-reactive protein participates in the innate immune response removing bacteria and damaged cells by complement activation and opsonization, activating monocyte/macrophage to inflammatory cytokines production and preventing neutrophils migration (Petersen et al., 2004). The blood C-reactive protein level increases by varying amounts in response to a variety of bacteria and intracellular antigens of damaged cells, followed by opsonization by phagocytic cells or activation of the complement system (Murata et al., 2004). During the acute phase response, C-reactive protein increases 110-fold (Petersen et al., 2004), thus it can be considered as a moderate positive acute phase protein.

In chickens, natural infection with the protozoan parasites, Eimeria tenella and Histomonas sp. induces a high level of Creactive protein (Chamanza et al., 1999a). Patterson and Mora (1965) found that C-reactive protein did not rise in chickens as quickly as it does in humans, whereby C-reactive protein was detectable 36-48 hours post infection in chickens, compared to 16-18 hours in humans. A more recent study found C-reactive protein levels to increase in broilers (Sohail et al., 2010). Patterson and Mora (1964) found C-reactive protein to be present in chicken serum with $E$. coli, Pasturella multocida and $S$. aureus infections, as well as histomoniasis and adjuvant injection, which highlights the use of C-reactive protein as a potential biomarker for non-clinical disease.

\subsection{Haptoglobin}

The primary function of haptoglobin is to bind free hemoglobin released from erythrocytes, and thereby inhibit its oxidative activity (Yang et al., 2003). The main function of haptoglobin is binding hemoglobin to prevent losses of iron via urine after haemolysis, thus, protecting tissues from being damaged by free hemoglobin (Petersen et al., 2004). Haptoglobin has been identified as a strong angiogenic agent required for the proliferation and differentiation of endothelial cells in the formation of new blood vessels (Park et al., 2009), and as a modulator of the immune system, i.e. it inhibits the activation of neutrophils. Haptoglobin develops a bacteriostatic effect that reducing the level of available iron for the microorganisms (Petersen et al., 2004). The haptoglobinhemoglobin binding also reduces the availability of the haem residue for bacterial growth (Murata et al., 2004).

Studies indicated the significance of haptoglobin as a clinically useful parameter for measuring the occurrence and severity of inflammatory responses in chickens with various diseases/ disorders. Haptoglobin level was significantly higher in non-vaccinated challenged birds compared to vaccinated challenged ones (Firouzi et al., 2014). Chickens infected with E. coli show significant increases in haptoglobin level (Rath et al., 2009; Georgieva et al., 2010). The higher level of haptoglobin in diseased birds could indicate inflammatory reaction following infection with ulcerative enteritis (Nazifi et al., 2011b). Chickens infected with fowl typhoid ( $S$. gallinarum) (Garcia et al., 2009), infectious bronchitis virus (Nazifi et al., 2011b; Asasi et al., 2013), retained yolk sac (Mosleh et al., 2012) and Gumboro (Nazifi et al., 2010) showed a significant increase in haptoglobin. As a result of parenteral administration of S. typhimurium LPS, haptoglobin serum levels significantly increased 1.5 fold (Millet et al., 2007), thus haptoglobin can be considered as a minor positive acute phase protein. Thus, the previous results suggest that haptoglobin could be a useful marker for diagnosis of diseases in chickens.

\subsection{Transferrin-ovotransferrin}

Transferrin is involved in sequestering ferric ions to prevent pathogens and parasites from utilizing them (Murata et al., 2004). The primary role of transferrin is to transport iron safely around the body to supply growing cells (Huebers and Finch, 1987). Transferrin inhibits multiplication and growth of certain viral, bacterial and fungal organisms by limiting their access to iron (Tothova et al., 2014). It has recently been shown that chicken ovotransferrin is actually the same molecule as transferrin. Both serum transferrin and ovotransferrin are identical with some glycosylation differences (Lambert et al., 2005). There is an evidence that ovotransferrin can modulate macrophage and heterophil function in chickens (Xie et al., 2002a). Chicken ovotransferrin is a moderate positive acute phase protein and increases 1-10fold in circulating level in response to a trigger 
(Cray et al., 2009) and remains elevated as long as inflammation persists (Rath et al., 2009). A number of studies confirming that serum ovotransferrin levels increase during an acute phase response due to a variety of experimentally induced infections and inflammatory processes. Ovotransferrin has immunomodulatory effects inducing respiratory burst activity, degranulation in heterophils, macrophages, facilitates tissue remodelling, angiogenesis, and aiding post inflammatory repair of tissues (Xie et al., 2002b).

Ovotransferrin level is significantly elevated under chemical-, bacterial-, and viral-induced inflammation (Xie et al., 2002a, b). Also, binding free iron; which is an essential nutrient for bacterial growth (Skaar, 2010); ovotransferrin limits infection by both grampositive and gram-negative bacteria (Superti et al., 2007). Ovotransferrin also contains a bactericidal domain that functions independently of the protein's iron-binding properties (Ibrahim et al., 1998). This domain causes selective ion efflux through bacterial membranes, which can also lead to bacteriostasis (Aguilera et al., 2003). The ovotransferrin exhibits antiviral (Giansanti et al., 2007) and antifungal activities (Valenti et al., 1985), and it has an immunomodulatory role in birds (Xie et al., 2002b).

It is hypothesized that ovotransferrin levels may be elevated in birds with metabolic stress because such conditions could produce damage in tissues such as the lungs and growth plate cartilage, respectively (Rath et al., 2009). Ovotransferrin elevation was also evident from the evaluation of sera from Smyth line birds with active Vitiligo, an autoimmune-autoinflammatory disease resulting in the loss of melanocytes (Rath et al., 2008). An elevated level of ovotransferrin during infection may serve as an immunomodulator (Xie et al., 2003), prevent microbial growth (Giansanti et al., 2007), and possibly act as an antioxidant against Fenton reaction mechanisms, which potentially generate free radicals involved in oxidative tissue damage (Superti et al., 2007). Also, ovotransferrin has been shown to be associated with the angiogenesis process in chickens (Cermelli et al., 2000). Angiogenesis is an important aspect of postinflammatory wound healing (Eming et al., 2007), and the elevation of ovotransferrin may be a protective mechanism responsible for restoring homeostasis (Rath et al., 2009). Chickens infected with E. coli and E. tenella show significant increases in ovotransferrin level
(Rath et al., 2009; Georgieva et al., 2010). In the croton oil-injected chickens inflammatory serum appeared have increased levels of ovotransferrin. When chickens were infected with microbes such as the bacterium, E. coli or the protozoan parasites, E. maxima and E. tenella, there was a significant increase in the levels of ovotransferrin in the serum (Tohjo et al., 1995). Rath et al. (2009) compared changes in the serum ovotransferrin level due to infectious diseases, metabolic diseases and autoimmune disease. Infectious diseases showed the biggest elevation, increasing ovotransferrin up to four fold. Autoimmune Vitiligo resulted in an increase in serum ovotransferrin though the birds with tibial dyschondroplasia, pulmonary hypertension syndrome and femoral head separation disorder did not show elevations in serum ovotransferrin (Durairaj et al., 2009; Rath et al., 2009). Sylte and Suarez (2012) also measured ovotransferrin alongside alpha-1-acid glycoprotein and found that chickens receiving a vaccine had significantly lower serum ovotransferrin at 48 and 96 hours post infection than those chickens that did not receive the vaccine. These studies suggest that ovotransferrin level is modulated under inflammatory and microbial stress and can therefore be used as a diagnostic marker of infection and inflammation in chickens.

\subsection{Ceruloplasmin}

The ceruloplasmin is a major copper-carrying protein in the blood, and plays a role in iron metabolism (Lovstad, 2006). Ceruloplasmin carries about $70 \%$ of the total copper in plasma and thus may play a role in $\mathrm{Cu}$ homeostasis (Martinez-Subiela et al., 2007). Ceruloplasmin can act as an anti-inflammatory agent reducing the number of neutrophils that attach to the endothelium, and as an extracellular scavenger of peroxide (Murata et al., 2004). Avian blood is very low in copper compared to mammals and has lower serum levels of ceruloplasmin (Disilvestro and Harris, 1985). Ceruloplasmin donates copper in a regulatory fashion with evidence of ceruloplasmin receptors on the membranes of numerous different cell types, supporting ceruloplasmin's role as a cell signaling multifunctional enzyme within many different metabolic pathways (Floris et al., 2000). Ceruloplasmin is an antioxidant protein, scavenging reactive oxygen species and preventing their formation through its involvement in iron homeostasis (Floris et al., 2000). 
Butler et al. (1972) first described ceruloplasmin as an acute phase protein in chickens when it was noted that a single injection of endotoxin from E. coli increased serum ceruloplasmin levels by 2 - to 5 -fold. The maximal increase in ceruloplasmin levels was 24 hours post injection with levels still detectable 48 hours after injection. In chickens, ceruloplasmin is considered as moderate positive acute phase protein increasing upon stimulation. Injection with $E$. coli endotoxin immediately produces a $50 \%$ increase in chicken ceruloplasmin level and higher level has been reported after infection with $E$. tenella (Chamanza et al., 1999a). The increase of ceruloplasmin in chicken serum after infecting the birds with $E$. coli or administering $E$. coli LPS is reported (Curtis and Butler, 1980). The changes in ceruloplasmin level were faster in the case of bacterial infection than in viral infection (Mazur-Gonkowska et al., 2004). S. gallinarum delivered into the crop of chickens showed ceruloplasmin to increase serum ceruloplasmin levels measured 3 to 5 days post infection (Garcia et al., 2009). Serum ceruloplasmin increases significantly in response to E. tenella infection (Georgieva et al., 2010) and combined E. coli and E. tenella infection (Georgieva et al., 2010).

\subsection{Fibrinogen}

Fibrinogen is a soluble glycoprotein present in the plasma of all vertebrates (Ceron et al., 2005). It is synthesized by hepatocytes and it is considered as a key regulator of inflammation during disease. Importantly the proinflammatory functions of fibrinogen are a product of fibrinogen signaling through binding sites that do not overlap with those involved in the coagulation cascade (Davalos and Akassoglou, 2012). During an acute phase response the vascular disruption associated with pathological events such as inflammation, infection and tissue injury cause the level of fibrinogen in the blood to increase (Davalos and Akassoglou, 2012). The fibrinogen is involved in homeostasis, providing a substrate for fibrin formation, and in tissues repair providing a matrix for the migration of inflammatory-related cells (Murata et al., 2004). During an inflammatory reaction, the fibrinogen level increases 2- to 3-fold, which may increase blood viscosity and cause red blood cell aggregation, and contribute to the growth of atherosclerotic plaques (Medcalf, 2007). Thus, fibrinogen is considered as a minor positive acute phase protein.
In chickens, fibrinogen has been used to evaluate inflammatory and traumatic diseases, and is characterized by markedly increased synthesis in response to infection (Georgieva et al., 2010). After treatment with turpentine, chickens fibrinogen was found to raise 3- to 4-fold (Amrani et al., 1986).

The level of fibrinogen in E. coli infected birds increased and was higher when compared with fibrinogen level in the haemorrhagic enteritis virus infected group (MazurGonkowska et al., 2004). In addition, fibrinogen level was faster in the case of bacterial infection than viral one (Mazur-Gonkowska et al., 2004). Injection of chickens with turpentine results in elevated levels (2-fold) of fibrinogen (Grieninger et al., 1986). Georgieva et al. (2010) found fibrinogen levels increased significantly in response to combined infection of $E$. coli and $E$. tenella.

\subsection{Alpha-1-Acid glycoprotein}

Alpha-1-acid glycoprotein is a highly glycosylated protein synthesized and secreted by hepatocytes (Ceron et al., 2005). Alpha-1-acid glycoprotein, a moderate positive acute phase protein in most mammals, appears to have a significant role in the early stages of inflammation and infection in chickens. The alpha-1-acid glycoprotein is a natural antiinflammatory agent that inhibits neutrophil activation and increases the secretion of interleukin-1 receptor antagonist by macrophages. Alpha-1-acid glycoprotein involves in the clearance of LPS by direct binding, thus neutralizing its toxicity (Murata $e t$ al., 2004). It has also been suggested that alpha1 -acid glycoprotein is required to maintain capillary permeability (Fournier et al., 2000). Alpha-1-acid glycoprotein is one of the most important drug binding proteins in plasma with important pharmacokinetic implications (Huang and Ung, 2013). Alpha-1-acid glycoprotein has been analyzed in natural and induced infections of chickens and has been shown to increase in relation with infection severity (Inoue et al., 1997).

A number of studies has investigated alpha-1acid glycoprotein in chickens in response to bacterial and viral infection. High alpha-1-acid glycoprotein level has been recorded birds infected with infectious bronchitis, infectious laryngotracheitis, infectious bursal disease viruses, E. coli and S. enterica (Nakamura et al., 1998; Chamanza et al., 1999a). Significant increase in alpha-1-acid glycoprotein level in 
birds infected with infectious bursal disease virus has also been reported (Inoue et al., 1997; Nazifi et al., 2010). Following a single E. coli LPS injection alpha-1-acid glycoprotein levels increased 4-fold (Takahashi et al., 1998). A number of studies has investigated alpha-1-acid glycoprotein during viral infections both with and without vaccination. Experimental infection with infectious bronchitis and infectious larygotracheitis virus increased alpha-1-acid glycoprotein levels, with alpha-1-acid glycoprotein higher in infectious bronchitis than infectious larygotracheitis virus infected birds (Nakamura et al., 1996). Chickens challenged with low pathogenic avian influenza showed increases in alpha-1-acid glycoprotein up to 48 post infection; however those that received low pathogenic avian influenza vaccine were shown to have significantly lower alpha-1-acid glycoprotein levels than unvaccinated controls (Sylte and Suarez, 2012). Thus, the alpha-1-acid glycoprotein could be used as a measure of chickens' well-being.

\subsection{Albumin}

During the acute phase response the demand for amino acids for synthesis of the positive acute phase proteins is markedly increased, which necessitates reprioritization of hepatic protein synthesis (Tothova et al., 2014). Thus, albumin synthesis is down-regulated and amino acids are shunted into synthesis of positive acute phase proteins (Aldred and Schreiber, 1993). Albumin is responsible for about $75 \%$ of the osmotic pressure of plasma and is a major source of amino acids that can be utilized by an animal when necessary. Due to its small size and abundance albumin makes a large contribution to plasma colloid osmotic pressure (Tothova et al., 2014). Albumin has a relatively long half-life, 14-20 days; thereby it has been touted as a marker of chronic nutritional status. This acute phase protein has been established as an indicator of morbidity and mortality (Don and Kaysen, 2004). However, albumin is considered as a negative acute phase protein.

A significant decreased level of albumin in chickens after LPS-induced inflammation was reported (Xie et al., 2000). In chickens, croton oil injection induced a significant decrease in albumin level (Xie et al., 2002a). Also, oral infection with $S$. gallinarum in chickens resulted in lower albumin level (Kokosharov, 2006). Kaneko (1997) concluded that due to its small size molecule and osmotic sensitivity, albumin is selectively lost in renal and intestinal diseases, such as acute fowl typhoid (Kokosharov et al., 1997). Injection of chickens with turpentine results in a $50-75 \%$ drop of albumin normal levels (Grieninger et al., 1986; Adler et al., 2001).

\subsection{Mannan-binding lectin}

Mannan-binding lectin belongs to a group of proteins called collectins which have a carbohydrate recognition domain able to bind a variety of microorganisms including bacteria, viruses, fungi and parasites. Mannan-binding lectin, upon recognition of infectious agents, activates a number of cellular defense mechanisms including phagocytosis, modulation of cytokines and immunoglobulin secretion. Mannan-binding lectin is also able to activate the complement system through a distinct mannanbinding lectin pathway (Juul-Madsen et al., 2003; Schou et al., 2010). The mannan-binding lectin increases up to 3-fold after an infection, which is why mannan-binding lectin is defined as a minor positive acute phase protein (Thiel $e t$ al., 1992). Increased level of mannan-binding lectin was found in the liver from virus-infected chickens suggesting an increased synthesis during acute infection (Nielsen et al., 1998a). Mannan-binding lectin was detected on the surface and within infectious laryngotracheitisinfected tracheal cells and in the cytoplasm of splenic macrophage-like cells from infectious bursal disease virus-infected birds (Juul-Madsen et al., 2003). This strongly suggests that mannan-binding lectin has an active role in the chicken immune system. Complement activation is directly associated with mannan-binding lectin serum level (Juul-Madsen et al., 2003) supporting the hypothesis that the level mannanbinding lectin affects the degree of virus neutralization before the adaptive immune response takes over.

In chickens, mannan-binding lectin level increases 2-fold in birds infected with infectious bronchitis virus and infectious bursal disease virus (Nielsen et al., 1998b). In relation to bacterial infections, mannan-binding lectin showed a significant 2-fold increase when chickens were inoculated with S. typhimurium LPS (Millet et al., 2007). When examining the baseline serum mannan-binding lectin levels in relation to intra-tracheal inoculation of $P$. multocida, Schou et al. (2010) found that chickens had significantly higher mean mannanbinding lectin levels prior to infection compared to four weeks post infection, and those birds that developed a systemic infection following 
inoculation, had lower mean baseline mannanbinding lectin than those with no splenic invasion, suggesting that mannan-binding lectin plays a role in the chickens immune system in protecting against systemic $P$. multocida infection. Furthermore, when experimentally infected with infectious bronchitis virus, there were a 2.3-fold and 1.6-fold increase in mannanbinding lectin in the low and high lines respectively (Juul-Madsen et al., 2007).

\subsection{Fibronectin}

The finronectin is a large molecular weight glycoprotein synthesized in hepatocytes as a soluble plasma fibronectin and in tissues as an insoluble structural form of fibronectin, synthesized in fibroblasts, epithelial cells and other differentiated cell types (Labat-Robert, 2012). Fibronectin is widely expressed in multiple cell types and is critically important in vertebrate development (Pankov and Yamada, 2002). Fibronectin is able to bind biologically important molecules having binding sites for bacteria, collagen, fibrin, fibronectin itself and heparin (Labat-Robert,2012). Plasma fibronectin is a minor positive acute phase protein, increasing during an acute phase response and able to diffuse into tissues and form part of the fibrillar matrix (Labat-Robert, 2012) where, together with tissue fibronectin, it plays an important and active role in wound healing. Fibronectin influences a wide range of cellular properties such as growth, differentiation, migration and apoptosis (Ruoslahti and Reed, 1994), and interacts with macromolecules, cells and bacteria (Mosher and Furcht, 1981). After treating chickens with turpentine or LPS, fibronectin level increases 3- to 4-fold. Chicken hepatocytes secrete increased levels of fibronectin after treatment with glucocorticoid or chicken interleukin-6 (Chamanza et al., 1999a). Fibronectin increases during an inflammatory response in chickens (Amrani et al., 1986). In response to dexamethasone administration, fibronectin in chicken increased 1.6 and 2.5 fold respectively from basal levels and remained elevated for 52 hours (Licheng et al., 2000).

\subsection{Hemopexin}

Hemopexin is a haem binding protein and an established acute phase protein in chickens (Adler et al., 2001). Hemopexin binds to the non-protein pyrrole rings within the haem molecule. Its predominant function is to sequester and transport haem, though it is a multifunctional protein having involvement in iron homeostasis, antioxidant production and signaling pathways that promote cell survival and gene expression (Tolosano et al., 2010). The role of hemopexin is to bind and transport free haem to the liver where it is internalized and degraded, thus preventing haem-mediated oxidative stress and haem-bound iron loss (Stred et al., 2003).

After treatment with E. coli LPS chicken hemopexin increased 3-fold (Adler et al., 2001), thus it is considered as a minor positive acute phase protein. Injection of chickens with turpentine results in elevated hemopexin level (5-fold). Barnes et al. (2002) used E. coli LPS to induce an acute phase response found a 2.6-fold increase in hemopexin. Adler et al. (2001) used S. typhimurium LPS found hemopexin levels to increase 3-fold at 24 hours post infection, hemopexin levels were still significantly higher than the control birds 14 days after the LPS challenge. Garcia et al. (2009) found hemopexin to increase by 1.5 -fold in response to intra crop $S$. gallinarum, with serum level decreasing from seven days post infection. Establishing the behavior of hemopexin in response to different infections over a period longer than 14 days would allow hemopexin behavior during an acute phase response to be fully characterized in chickens.

\section{Acute phase proteins and stress}

Birds are exposed to a variety of external and internal stressors including temperature, transportation, stocking density, feed restriction, feed contamination and fear (Hangalapura et al., 2006; Delezie et al., 2007). Environmental stressors such as heat/cold stress influenced cellmediated immunity of chickens (Hangalapura et al., 2006). High ambient temperatures result in economic loss and reduced chickens welfare (Mack et al., 2013). Stress affects live weight, feed efficiency, eggs' production and quality, fertility, hatchability and survival of chickens (Karaman et al., 2007; Ajakaiye et al., 2011). Seemingly, the chickens industry will face a greater problem associated with heat stress in the near future, as the continuously changing global climate lengthens the hot season and increases the geographic areas affected by high environmental temperatures (Hansen et al., 2010). Although the chickens acute phase proteins during infection and inflammation has been documented (Chamanza et al., 1999a; O'Reilly and Eckersall, 2014), changes in acute phase proteins as a result of nonpathogenic stimulus are still unclear in chickens. However, diagnostics of stresses in chickens farming is an 
important issue, intended to solve some adjacent tasks (Tikhonov and Miftakhutdinov, 2014). Nowadays, there is no single approach to stress diagnostics in chickens farming (Dawkins, 2003), and methods worked out have advantages and disadvantages that demand very careful choice of the stress markers from the researchers.

Studies showed that the response of the stressed chickens includes elevated levels of hemopexin and fibrinogen (5- and 2-fold, respectively) accompanied by a $50 \%$ drop in Albumin (Grieninger et al., 1986). Temperature increases alpha-1-acid glycoprotein levels (Najafi et al., 2015), and fibronectin levels (JianHua et al., 2000) in chickens. Administration of corticosterone increased alpha-1-acid glycoprotein significantly, thus, alpha-1-acid glycoprotein may be of value as indicators of stress in chickens (Zulkifli et al., 2014). Salamano et al. (2010) reported that hens kept in both conventional and modified battery cages had higher alpha-1-acid glycoprotein than those in the free-range system. In addition, cold stress has been reported to enhance proinflammatory cytokines (Hangalapura et al., 2006). Furthermore, high stocking density with feed restriction in birds markedly affected the cell-mediated immune responses by increasing pro-inflammatory cytokines, leading to potential modulation of immunity in birds (Kang et al., 2011).

However, Table (1) summarizes the main acute phase proteins reported in chickens infected with various bacterial, viral and parasitic agents. In addition, the chickens acute phase proteins during inflammation are presented in table 1. Furthermore, the table shows some important acute phase proteins in chickens under various kinds of stressors (i.e. heat, psychological and physical stressors).

\section{Conclusions}

Infectious and metabolic disorders are common in chickens and cause stress, poor performance and mortality that result in considerable economic loss. Identifying the nature of stress in chickens will assist in developing appropriate measures to improve health and welfare. The use of acute phase proteins as nonspecific biomarkers has got high potential in modern veterinary practice for health assessment in animal disease diagnosis, pathogenesis of various diseases in chickens, and spread of infection or the efficacy of treatment. Acute phase proteins quickly and precisely dem- onstrate the presence of infectious and the intensity of inflammatory conditions, but not the cause. Acute phase proteins are more useful for monitoring health than the cytokines, because cytokines are cleared from the circulation within a few hours, whereas acute phase proteins' levels after a single stimulus remain unchanged for at least $48 \mathrm{~h}$. The possible use of acute phase proteins in chickens has been investigated in various inflammatory and non-inflammatory conditions, and in experimental infections and natural diseases (specific bacterial, viral or parasitic infections) which provide data for veterinarians and producers regarding the possible use of acute phase proteins as biomarkers of diseases in chickens.

In chickens, acute phase proteins could be used to detect the infection by many bacteria $(E$. coli, S. gallinarum/typhimurium, P. multocida and $S$. aureus), viruses (infectious bronchitis, ulcerative enteritis, retained yolk sac, infectious bursal disease, infectious laryngotracheitis, reticuloendothelial virus and some others), and gastrointestinal protozoan parasites (E. tenella, E. maxima, E. acervulina and Histomonas). Acute phase proteins could also be used to gauge stress with regard to chickens' well-being, and stressors that could be assessed in future studies of chickens include physical environment (lighting, temperature and noise), housing type, husbandry, handling, and shipping. However, the monitoring of two or more acute phase proteins is highly valuable in different diseases as each acute phase protein may display a different kinetic after the infection/trauma in the bird. Furthermore, it has suggested that a single acute phase protein should not be exclusively used to monitor a disease process. Instead, an acute phase protein index should be used in veterinary medicine.

This index includes both positive and negative acute phase proteins, and acute phase proteins that increase rapidly and slowly, thereby forming a comprehensive index that would correlate with the severity of the inflammatory process.

Most methods available for measuring specific acute phase proteins are immunological techniques, which are time-consuming and relatively expensive, and so limit the wide-scale use of acute phase proteins in routine practice. Rapid and reliable diagnostic assay kits need to be available at an economic price to be used by diagnostic laboratories. As there is a broad spectrum of possible applications of acute phase 
Table (1): Main acute phase proteins reported in different disorders in chickens.

\begin{tabular}{|c|c|c|c|}
\hline Infectious agent & Disorder & APP & Reference \\
\hline \multirow[t]{17}{*}{ Bacterial } & \multirow[t]{7}{*}{ Escherichia coli (LPS) } & AGP & $\begin{array}{l}\text { Buyse et al., 2007; Takahashi } \text { et } \\
\text { al., } 2009\end{array}$ \\
\hline & & HPX & $\begin{array}{l}\text { Adler } \text { et al., 2001; Barnes et al., } \\
\text { 2002; Buyse et al., } 2007\end{array}$ \\
\hline & & Cp, Fbg & $\begin{array}{l}\text { Mazur-Gonkowska et al., } 2004 \\
\text { Takahashi et al., } 2009\end{array}$ \\
\hline & & Hp & $\begin{array}{l}\text { Rath } \text { et al., 2009; Georgieva } \text { et } \\
\text { al., } 2010\end{array}$ \\
\hline & & SAA & Chamanza et al., 1999a \\
\hline & & OVT & $\begin{array}{l}\text { Xie et al., 2002b; Tohjo e al., } \\
1995\end{array}$ \\
\hline & & CRP & Patterson and Mora 1965 \\
\hline & \multirow{6}{*}{$\begin{array}{l}\text { Salmonella gallinarum } \\
\text { Salmonella typhimurium }\end{array}$} & $\mathbf{C P}$ & Song et al., 2009 \\
\hline & & $\mathbf{H X}$ & $\begin{array}{l}\text { Adler } \text { et al., 2001; Garcia } \text { et al., } \\
2009\end{array}$ \\
\hline & & Cp, OVT & Garcia et al., 2009 \\
\hline & & MBL & Millet et al., 2007 \\
\hline & & Alb & Kokosharov, 2006 \\
\hline & & Hp & $\begin{array}{l}\text { Millet et al., 2007; Garcia et al., } \\
2009\end{array}$ \\
\hline & \multirow[t]{2}{*}{ Staphylococcus aureus } & SAA & $\begin{array}{l}\text { Chamanza et al., 1999a; } \\
\text { Upragarin, 2005 }\end{array}$ \\
\hline & & CRP & Patterson and Mora, 1964 \\
\hline & \multirow[t]{2}{*}{ Pasteurella multocida } & MBL & Schou et al., 2010 \\
\hline & & CRP & Patterson and Mora, 1964 \\
\hline \multirow{18}{*}{ Viral } & \multirow{4}{*}{ Infectious bronchitis } & AGP & Nakamura et al., 1996, 1998 \\
\hline & & Hp, SAA & $\begin{array}{l}\text { Nazifi et al., 2011a, b } \\
\text { Asasi } \text { et al., } 2013\end{array}$ \\
\hline & & OVT & Xie et al., 2002b \\
\hline & & MBL & Juul-Madsen et al., 2003; 2007 \\
\hline & Ulcerative enteritis & SAA, Hp & Nazifi et al., 2011a, b \\
\hline & Retained yolk sac & Hр, SAA & Mosleh et al., 2012 \\
\hline & \multirow[t]{4}{*}{$\begin{array}{l}\text { Infectious bursal } \\
\text { disease }\end{array}$} & MBL & $\begin{array}{l}\text { Nielsen } \text { et al., 1998a } \\
\text { Juul-Madsen } \text { et al., } 2003\end{array}$ \\
\hline & & AGP & Nakamura et al., 1998; \\
\hline & & Cp, SAA, Hp, Fbg & Nazifi et al., 2010 \\
\hline & & OVT & Xie et al., 2002b \\
\hline & \multirow{3}{*}{$\begin{array}{l}\text { Infectious } \\
\text { laryngotracheitis virus }\end{array}$} & AGP & Nakamura et al., 1996, 1998 \\
\hline & & OVT & Xie et al., 2002b \\
\hline & & MBL & Nielsen et al., 1998a \\
\hline & $\begin{array}{l}\text { Reticuloendothelial } \\
\text { virus }\end{array}$ & Tf & Rath et al., 2009 \\
\hline & $\begin{array}{l}\text { Haemorrhagic enteritis } \\
\text { virus }\end{array}$ & Fbg & Mazur-Gonkowska et al., 2004 \\
\hline & $\begin{array}{l}\text { Respiratory enteric } \\
\text { orphan }\end{array}$ & OVT & Xie et al., 2002b \\
\hline & Fowl Poxvirus & OVT & Xie et al., 2002b \\
\hline & $\begin{array}{l}\text { Low pathogenic avian } \\
\text { influenza }\end{array}$ & AGP, OVT & Sylte and Suarez, 2012 \\
\hline \multirow[t]{5}{*}{ Parasitic } & \multirow{4}{*}{$\begin{array}{l}\text { Eimeria tenella, E. } \\
\text { maxima, E. acervulina } \\
\text { and histomonas }\end{array}$} & CRP & Chamanza et al., 1999a \\
\hline & & OVT & $\begin{array}{l}\text { Rath et al., 2009; Georgieva et } \\
\text { al., } 2010\end{array}$ \\
\hline & & $\mathbf{C P}$ & $\begin{array}{l}\text { Chamanza et al., 1999a } \\
\text { Georgieva } \text { et al., } 2010\end{array}$ \\
\hline & & Hp, Fbg & Georgieva et al., 2010 \\
\hline & Histomoniasis & CRP & Patterson and Mora, 1964 \\
\hline
\end{tabular}


Table: (1) Cont.

\begin{tabular}{|c|c|c|c|}
\hline \multirow[t]{7}{*}{ Inflammation } & \multirow[t]{3}{*}{ Turpentine injection } & $\begin{array}{l}\text { Fbg, Alb, } \\
\text { HPX }\end{array}$ & Grieninger et al., 1986 \\
\hline & & $\begin{array}{l}\text { SAA, FN, } \\
\text { OVT }\end{array}$ & Chamanza et al., 1999a \\
\hline & & Tf & Tohjo et al., 1995 \\
\hline & Corticosterone administration & OVT, AGP & Zulkifli et al., 2014 \\
\hline & Acute lesions & SAA & Chamanza et al., 1999a \\
\hline & Glucocorticoid treatment & Fbg & Chamanza et al., 1999a \\
\hline & Non-vaccinated challenged birds & Hp, SAA & Firouzi et al., 2014 \\
\hline \multirow[t]{2}{*}{$\begin{array}{l}\text { Immune mediated } \\
\text { metabolic }\end{array}$} & $\begin{array}{l}\text { Autoimmune vitiligo } \\
\text { Tibial dyschondroplasia } \\
\text { Pulmonary hypertension }\end{array}$ & OVT & Rath et al., 2009 \\
\hline & Femoral head separation & OVT & Durairaj et al., 2009 \\
\hline \multirow{5}{*}{ Other (Stress) } & Heat stress & AGP & Najafi et al., 2015 \\
\hline & Heat stress & Fbg & Jianhua et al., 2000 \\
\hline & Psychological stress & OVT & Rath et al., 2009 \\
\hline & Psychological stress & HPX & Grieninger et al., 1986 \\
\hline & Physical stress & AGP & Salamano et al., 2010 \\
\hline
\end{tabular}

SAA: Serum amyloid A; CRP: C-reactive protein; Hp: Haptoglobin; AGP: a1-acid glycoprotein; Cp: Ceruloplasmin; Fbg: Fibrinogen; Alb: Albumin; FN: Fibronectin; HPX: Hemopexin; Tf: Transferrin; MBL: Mannan-binding lectin; OVT: Ovotransferrin.

proteins-based diagnostics in chickens, it is necessary to develop and optimize rapid field tests that allow the measurement of acute phase proteins' levels in a short time period. New technologies need to be developed for economically feasible estimation of acute phase proteins. More research is needed to be done for making these biomarkers a perfect predictive tool for chickens' health status. Furthermore, data highlight that the acute phase proteins levels should be adjusted for factors such as age, sex and genetic line, being needed the determination of a reference range which allow a reliable use of acute phase proteins measurement in chickens. Furthermore, the harmonization of assay calibration between laboratories will be a major practical advance for the future prospects in the application of acute phase protein assays to chickens health and welfare. In the future, measurement of acute phase proteins could have further applications in the identification of diseased chickens at slaughter and for monitoring the presence of sub-clinical disease leading to poor growth rates on farms. Finally, this review highlights research gaps and directions deserving further development to create a better understanding of acute phase proteins for making these biomarkers a perfect predictive tool for chickens health status and valuable diagnostic approaches in chickens. It is hoped that review will help in using acute phase proteins in diseases' diagnosing and treatment monitoring, which are the most promising practical uses of acute phase proteins.

\section{REFERENCES}

Abernethy T.J. and Avery O.T. (1941). The occurrence during acute infections of a protein not normally present in the blood. J. Exper. Med., 73: 173-182.

Adler K.L., Peng P.H., Peng R.K. and Klasing K.C. (2001). The kinetics of hemopexin and $\alpha 1$-acid glycoprotein levels induced by injection of inflammatory agents in chickens. Avian Dis., 45: 289-296.

Aguilera O., Quiros L.M. and Fierro J.F. (2003). Transferrins selectively cause ion efflux through bacterial and artificial membranes. FEBS Lett., 548: 5-10.

Ajakaiye J.J., Perez-Bello A. and MollinedaTrujillo A. (2011). Impact of heat stress on egg quality in layer hens supplemented 
with 1-ascorbic acid and dl-tocopherol acetate. Vet. Arhiv., 81: 119-132.

Alasonyalilar A., Sevimli A., Misirlioglu D. and Uguz C. (2006). Chronic amyloid arthropathy and increased serum amyloid levels in brown layers. Bull. Vet. Inst. Pul., 50: 557-560.

Aldred A.R. and Schreiber G. (1993). The negative acute phase protein. In: Acute phase proteins: molecular biology, biochemistry and clinical applications, Mackiewicz I., Kushner I. and Baumann H. (eds), CRC Press, Boca Raton, Florida, USA. pp. 21-37.

Amrani D.L., Mauzy-Melitz D. and Mosesson M.W. (1986). Effect of hepatocytestimulating factor and glucocorticoids on plasma fibronectin levels. Biochem. J., 238: 365-371.

Asasi K., Mohammadi A., Boroomand Z., Hosseinian S.A. and Nazifi S. (2013). Changes of several acute phase factors in broiler chickens in response to infectious bronchitis virus infection. Poult. Sci., 92: 1989-1996.

Barnes D.M., Song Z., Klasing K.C. and Bottje W. (2002). Protein metabolism during an acute phase response in chickens. Amino Acids, 22: 15-26.

Baumann H. and Gauldie J. (1994). The acute phase response. Immunol. Today 15: 7480.

Blatteis C.M. (2006). Endotoxic fever: new concepts of its regulation suggest new approaches to its management. Pharmacol. Ther., 111: 194-223.

Bochsler P.N. and Slauson D.O. (2002). Inflammation and repair of tissue. In: Mechanism of disease. A Textbook of Comparative General Pathology, Bochcler P.N. and Slauson D.O. (eds), $3^{\text {rd }}$ edn., Mosby, St. Louis, USA. pp. 140-245.

Butler E.J., Curtis M.J., Harry E.G. and Deb J.R. (1972). Effects of Escherichia coli endotoxins on plasma paraphenylenediamine oxidase (caeruloplasmin) activity in the domestic fowl. J. Comp. Pathol., 82: 299-306.

Buyse J., Swennen Q., Niewold T.A., Klasing K.C., Janssens G.P.J., Baumgartner M. and Goddeeris B.M. (2007). Dietary Lcarnitine supplementation enhances the lipopolysaccharide induced acute phase protein response in broiler chickens. Vet. Immunol. Immunopathol., 118: 154-159.
Ceciliani F., Ceron J.J., Eckersall P.D. and Sauerwein H. (2012). Acute phase proteins in ruminants. J. Proteomics, 75 : 4207-4231.

Ceciliani F., Giordano A. and Spagnolo V. (2002). The systemic reaction during inflammation: the acute-phase proteins. Protein Pept. Lett., 9: 211-223.

Cermelli S., Zerega B., Carlevaro M., Gentili C., Thorp B., Farquharson C., Cancedda R. and Cancedda F.D. (2000). Extracellular fatty acid binding protein (Ex-FABP) modulation by inflammatory agents: physiological acute phase response in endochondral bone formation. Eur. J. Cell Biol., 79: 155-164.

Ceron J.J., Eckersall P.D. and Martinez-Subiela S. (2005). Acute phase proteins in dogs and cats: current knowledge and future perspectives. Vet. Clin. Pathol., 34: 85-99.

Chamanza M.J., Toussaint A.M., van Ederen A.M., van Veen L., Hulskamp-Koch C. and Fabri T.H. (1999a). Serum amyloid A and transferrin in chicken: a preliminary investigation of using acute phase variables to assess disease in chickens. Vet. Q., 21: 158-162.

Chamanza M.J., van Veenm L., Tivapasi M.T. and Toussiant M.J.M. (1999b). Acute phase proteins in the domestic fowl. World's Poult. Sci. J., 55: 61-71.

Cray C., Zaias J. and Altman N.H. (2009). Acute phase response in animals: a review. Comp. Med., 59: 517-526.

Curtis M.J. and Butler E.J. (1980). Response of caeruloplasmin to Escherichia coli endotoxins and adrenal hormones in the domestic fowl. Res. Vet. Sci., 28: $217-$ 222.

Davalos D. and Akassoglou K. (2012). Fibrinogen as a key regulator of inflammation in disease. Semin. Immunopathol., 34: 43-62.

Davison F., Kaspers B. and Schat K.A. (2008). Avian Immunology. Elsevier Ltd. San Diego, CA, USA. pp. 481.

Dawkins M.S. (2003). Behavior as a tool in the assessment of animal welfare. Zoology, 106: 383-387.

Delezie E., Swennen Q., Buyse J. and Decuypere E. (2007). The effect of feed withdrawal and crating density in transit on metabolism and meat quality of broilers at slaughter weight. Poult. Sci., 86: 1414-1423. 
Disilvestro R.A. and Harris E.D. (1985). Purification and partial characterization of ceruloplasmin from chicken serum. Arch. Biochem. Biophys., 241: 438-446.

Don B.R. and Kaysen G. (2004). Serum albumin: relationship to inflammation and nutrition. Semin. Dial. 17: 432-437.

Durairaj V., Okimoto R., Rasaputra K., Clark F.D. and Rath N.C. (2009). Histopathology and serum clinical chemistry evaluation of broilers with femoral head separation disorder. Avian Dis., 53: 21-25.

Eckersall P.D. (2000). Acute phase proteins as markers of infection and inflammation: monitoring animal health, animal welfare and food safety. Irish Vet. J., 53: 307-311.

Eckersall P.D. (2004). The time is right for acute phase protein assays. Vet. J., 168: 3-5.

Eckersall P.D. and Bell R. (2010). Acute phase proteins: biomarkers of infection and inflammation in veterinary medicine. Vet. J., 185: 23-27.

Eming S.A., Brachvogel B., Odorisio T. and Koch M. (2007). Regulation of angiogenesis: wound healing as a model. Prog. Histochem. Cytochem., 42: 115-70.

Firouzi S., Nili H., Asasi K., Nazifi S., Mosleh N., Habibi H. and Mohammadi M. (2014). Acute phase responses in commercial broiler chickens experimentally infected with a highly virulent Newcastle disease virus strain. Onl. J. Vet. Res., 18: 495502.

Floris G., Medda R., Padiglia A. and Musci G. (2000). The physiopathological significance of ceruloplasmin. Biochem. Pharmacol., 60: 1735-1741.

Fournier T., Medjoubi N. and Porquet D. (2000). Alpha-1-acid glycoprotein. Biochim. Biophys. Acta, 1482: 157-171.

Gabay C. and Kushner I. (1999). Acute-phase proteins and other systemic responses to inflammation. N. Engl. J. Med., 340: 448454.

Garcia K.O., Berchieri A., Santana A.M., Freitas-Neto O.C. and Fagliari J.J. (2009). Experimental infection of commercial layers using a Salmonella enterica serovar Gallinarum strain: leukogram and serum acute-phase protein concentrations. Braz. J. Poult. Sci., 11: 263-270.

Georgieva T.M., Koinarski V.N., Urumova V.S., Marutsov P.D., Christov T.T., Nikolov J., Chaprazov T., Walshe K., Karov R.S.,
Georgiev I.P. and Koinarski Z.V. (2010). Effects of Escherichia coli infection and Eimeria tenella invasion on blood concentrations of some positive acute phase proteins (haptoglobin (PIT 54), fibrinogen and ceruloplasmin) in chickens. Rev. De Med. Vet., 161: 84-89.

Giansanti F., Giardi M.F., Massucci M.T., Botti D. and Antonini G. (2007). Ovotransferrin expression and release by chicken cell lines infected with Marek's disease virus. Biochem. Cell Biol., 85: 150-155.

Gómez-Laguna J., Salguero F.J., Pallares F.J., Rodriguez-Gomez I.M., Barranco I. and Carrasco L. (2011). Acute phase proteins as early nonspecific biomarkers of human and veterinary diseases. Veas F. (eds), Ch. 12, In Tech, Montpellier, France, pp. 408.

Grieninger G., Liang T.J., Beuving G., Goldfarb V., Metcalfe S.A. and Muller-Eberhard U. (1986). Hemopexin is a develop-mentally regulated, acute-phase plasma protein in the chicken. J. Biol. Chem., 261: 1571915724.

Gruys E., Obwolo M.J. and Toussaint M.J.M. (1994). Diagnostic significance of the major acute phase proteins in veterinary clinical chemistry: a review. Vet. Bull., 64:1009-1018.

Gruys E., Toussaint M.J., Niewold T.A., Koopmans S.J., van Dijk E. and Meloen R.H. (2006). Monitoring health by values of acute phase proteins. Acta Histochem., 108: 229-232.

Gruys E., Toussaint M.J., Upragarin N., Van E.A., Adewuyi A.A., Candiani D., Nguyen T.K. and Sabeckiene J. (2005). Acute phase reactants, challenge in the near future of animal production and veterinary medicine. J. Zhejiang Uni. Sci. B., 6: 941-947.

Hallquist N.A. and Klasing K.C. (1994). Serotransferrin, ovotransferrin and metallothionein levels during an immune response in chickens. Comp. Biochem. Physiol. Biochem. Mol. Biol., 108: 375384.

Hangalapura B.N., Kaiser M.G., Poel J.J., Parmentier H.K. and Lamont S.J. (2006). Cold stress equally enhances in vivo proinflammatory cytokine gene expression in chicken lines divergently selected for antibody responses. Dev. Comp. Immunol., 30: 503-511. 
Hansen J., Ruedy R., Sato M. and Lo K. (2010). Global surface temperature change. Rev. Geophys., 48: RG4004.

Helle M., Juul-Madsen R., Vierlboeck B., Smith A.L. and Gobel T.W.F. (2008). Avian Innate Immune Responses. In: Avian immunology, Davison F., Kaspers B. and Schat K.A. (eds), Elsevier Ltd. San Diego, USA, pp. 481.

Hiss S., Willbrenning G.S., Suntz M., Reinacher M. and Sauerwein H. (2008). Immunohisto-chemical localization of haptoglobin in porcine lungs. Anat. Histol. Embryol., 37: 196-199.

Holt P.S. and Gast R.K. (2002). Comparison of the effects of infection with Salmonella enteritidis in combination with an induced molt on serum levels of the acute phase protein $\alpha 1$-acid glycoprotein in hens. Poult. Sci., 81: 1295-1300.

Huang Z. and Ung T. (2013). Effect of alpha-1acid glycoprotein binding on pharmacokinetics and pharmacodynamics. Curr. Drug Metab., 14: 226-238.

Huebers H.A. and Finch C.A. (1987). The physiology of transferrin and transferring receptors. Physiol. Rev., 67: 520-582.

Ibrahim H.R., Iwamori E., Sugimoto Y. and Aoki T. (1998). Identification of a distinct antibacterial domain within the N-lobe of ovotransferrin. Biochim. Biophys. Acta, 1401: 289-303.

Inoue M., Satoh W. and Mukarami H. (1997). Plasma alpha-1-acid glycoprotein in chickens infected with infectious bursal disease virus. Avian Dis., 41: 164-170.

Jain S., Gautam V. and Naseem S. (2011). Acute-phase protein: as diagnostic tool. J. Pharm. Bioallied. Sci., 3: 118-127.

Janeway C.A., Travers P., Walport M. and Shlomchik M. (2001). The adaptive immune responses. In: Immunology, Janeway C.A. (eds), Garland Publishing New York, NY. USA. pp. 295-381.

Jensen L.E. and Whitehead A.S. (1998). Regulation of serum amyloid A protein expression during the acute phase response. Biochem. J., 334: 489-503.

Jianhua L., Licheng L., Jiushan J. and Hongkui L. (2000). Effects of high temperature on plasma fibronectin levels and serum biochemical parameters in broilers. Chinese J. Vet. Sci., 20: 591-593.

Juul-Madsen H.R., Munch M., Handberg K.J., Sorensen P., Johnson A.A., Norup L.R. and Jorgensen P.H. (2003). Serum levels of mannan-binding lectin in chickens prior to and during experimental infection with avian infectious bronchitis virus. Poult. Sci., 82: 235-241.

Juul-Madsen H.R., Norup L.R., Handberg K.J. and Jorgensen P.H. (2007). Mannanbinding lectin (MBL) serum concentration in relation to propagation of infectious bronchitis virus (IBV) in chickens. Viral Immunol., 20: 562-570.

Kaneko J.J. (1997). Serum proteins and the dysproteinemias. In: Clinical biochemistry of domestic animals, Kaneko J.J., Harvey J.W. and Bruss M.L. (eds), $5^{\text {th }}$ edn, San Diego CA, Academic Press pp. 117-138.

Kang S.Y., Ko Y.H., Moon Y.S., Sohn S.H. and Jang I.S. (2011). Effects of the combined stress induced by stocking density and feed restriction on hematological and cytokine parameters as stress indicators in laying hens. Asian-Aust. J. Anim. Sci., 24: 414-420.

Karaman S., Tarhan S. and Ergunes G. (2007). Analysis of indoor climatic data to assess the heat stress of laying hens. IJNES, 1:65-68.

Kent J. (1992). Acute phase proteins: their use in veterinary diagnosis. Br. Vet. J., 148: 279282.

Khan K.A., Khan S.A., Aslam A., Rabbani M. and Tipu M.Y. (2004). Factors contributing to yolk retention in poultry: a review. Pak. Vet. J., 24: 46-51.

Klasing K.C. (2004). The costs of immunity. Current Zoology. 50: 961-969.

Kokosharov T. (2006). Changes in the protein profile in birds with experimental acute fowl typhoid. Bulg. J. Vet. Med., 9: 189192.

Kokosharov T., Hristov H. and Belchev L. (1997). Clinical, bacteriological and pathological studies on experimental fowl typhoid. Ind. Vet. J., 74: 547-549.

Labat-Robert J. (2012). Cell-Matrix interactions, the role of fibronectin and integrins. A survey. Pathol. Biol., 60: 15-19.

Lambert L.A., Perri H., Halbrooks P.J. and Mason A.B. (2005). Evolution of the transferrin family: conservation of residues associated with iron and anion binding. Comp. Biochem. Physiol. B. Biochem. Mol. Biol., 142: 129-141.

Licheng L., Jianhua L., Jiushan J., Jixun Z. and Cheng H. (2000). Effect of ACTH and 
dexamethasone on plasma fibronectin levels and serum biochemical parameters in broilers. J. China Agric. Univ., Beijing, China, 5: $106-110$.

Lippolis J.D. (2008). Immunological signaling networks: integrating the body's immune response. J. Anim. Sci., 86: 53-63.

Lovstad R.A. (2006). A kinetic study on the phenothiazine dependent oxidation of NADH by bovine ceruloplasmin. Biometals 19: 1-5.

Mack L.A., Felver-Gant J.N., Dennis R.L. and Cheng H.W. (2013). Genetic variation alter production and behavioral responses following heat stress in 2 strains of laying hens. Poult. Sci., 92: 285-294.

Mack D.R., McDonald T.L., Larson M.A., Wei S.H. and Weber A. (2003). The conserved TFLK motif of mammary- associated serum amyloid A3 is responsible for upregulation of intestinal MUC3 mucin expression in vitro. Pediatr. Res., 53: 137142.

Martinez-Subiela S., Tecles F. and Ceron J.J. (2007). Comparison of two automated spectro-photometric methods for ceruloplasmin measurement in pigs. Res. Vet. Sci., 83: 12-19.

Mazur-Gonkowska B., Koncicki A. and Krasnodebska-Depta A. (2004). Assessment of acute phase response in turkeys experimentally infected with Escherichia coli or haemorrhagic enteritis virus. Bull. Vet. Inst. Pulawy, 48: 19-23.

Medcalf R.L. (2007). Fibrinolysis, inflammation and regulation of the plasminogen activating system. J. Thrombos. Haemost., 5: 132-142.

Millet S., Bennett J., Lee K.A., Hau M. and Klasing K.C. (2007). Quantifying and comparing constitutive immunity across avian species. Develop. Comp. Immunol., 31: 188-201.

Moshage H. (1997). Cytokines and the hepatic acute phase response. J. Pathol., 181: 257266.

Mosher D.F. and Furcht L.T. (1981). Fibronectin: review of its structure and possible functions. J. Invest. Dermatol., 77: 175-180.

Mosleh N., Nazifi S. and Alaeddini A. (2012). Changes in serum acute phase reactants, inflammatory mediators and gangliosides in Japanese quail (Coturnix japonica) with retained yolk sac. Pak. Vet. J., 32: 251254.

Murata H., Shimada N. and Yoshioka M. (2004). Current research on acute phase proteins in veterinary diagnosis: an overview. Vet. J., 168: 28-40.

Najafi P., Zulkifli I., Amat Jajuli N., Farjam A.S., Ramiah S.K., Amir A.A., O'Reily E. and Eckersall D. (2015). Environmental temperature and stocking density effects on acute phase proteins, heat shock protein 70 , circulating corticosterone and performance in broiler chickens. Int. J. Biometeorol., 59: 1577-1583.

Nakamura K., Imai K. and Tanimura N. (1996). Comparison of the effects of infectious bronchitis and infectious laryngotracheitis on the chicken respiratory tract. J. Comp. Pathol., 114: 11-21.

Nakamura K., Mitarai Y., Yoshioka M., Koizumi N., Shibahara T. and Nakajima Y. (1998). Serum levels of interleukin-6, a1-acid glycoprotein and corticosterone in two-week-old chickens inoculated with Escherichia coli lipopolysaccharide. Poult. Sci., 77: 908-911.

Nakamura M., Takahashi M., Ohno K., Koshino A., Nakashima K., Setoguchi A., Fujino Y. and Tsujimoto H. (2008). C-reactive protein concentration in dogs with various diseases. J. Vet. Med. Sci., 70: 127-131.

Nazifi S., Dadras H., Hoseinian S.A., AnsariLari M. and Masoudian M. (2010). Measuring acute phase proteins (haptoglobin, ceruloplasmin, serum amyloid A and fibrinogen) in healthy and infectious bursal disease virus-infected chicks. Comp. Clin. Pathol., 19: 283-286.

Nazifi S., Mosleh N., Alaeddini A., Eskandarzadeh N. and Basaki M. (2011a). Acute phase proteins in Japanese quail (Coturnix coturnix japonica) with ulcerative enteritis. J. Vet. Res., 15: 395403.

Nazifi S., Tabande M.R., Hoseinian S.A., Ansari-Lari M. and Safari H. (2011b). Evaluation of sialic acid and acute-phase proteins (haptoglobin and serum amyloids A) in healthy and avian infection bronchitis virus infected chicks. Comp. Clin. Pathol., 20: 69-73.

Nielsen O.L., Jorgensen P.H., Hedemand J.E., Jensenius J.C., Koch C. and Laursen S.B. (1998a). Immunohistochemical investigation of the tissue distribution of 
mannan-binding lectin in non-infected and virus-infected chickens. Immunol., 94: 122-128.

Nielsen O.L., Sorensen P., Hedemand J.E., Laursen S.B. and Jorgensen P.H. (1998b). Inflammatory response of different chicken lines and B haplotypes to infection with infectious bursal disease virus. Avian Pathol., 27: 181-189.

Niewold T.A., Toussaintand M.J.M. and Gruys E. (2003). Monitoring health by acute phase proteins. In: Proc. $4^{\text {th }}$ Eur. Coll. on APPs, Segovia, Spain, pp. 57-67.

O'Reilly E.L. and Eckersall P.D. (2014). Acute phase proteins: a review of their function, behaviour and measurement in chickens. World's Poult. Sci. J., 70: 27-44.

Owen-Ashley N.T. and Wingfield J.C. (2007). Acute phase responses of passerine birds: characterization and seasonal variation. J. Ornithol., 148: 583-591.

Pankov R. and Yamada K.M. (2002). Fibronectin at a glance. J. Cell Sci., 115: 3861-3863.

Park S.J., Baek S.H., Oh M.K., Choi S.H., Park E.H., Kim N.H., Shin J.C. and Kim I.S. (2009). Enhancement of angiogenic and vasculogenic potential of endothelial progenitor cells by haptoglobin. FEBS Lett., 583: 3235-3240.

Patterson L. T. and Mora E.C. (1964). Occurrence of a substance analogous to $\mathrm{C}$ reactive protein in the blood of the domestic fowl. Tex. Rep. Biol. Med., 22: 716-721.

Patterson L.T. and Mora E.C. (1965). The Creactive protein response and disease resistance in domestic fowl. Tex. Rep. Biol. Med., 23: 600-606.

Petersen H.H., Nielsen J.P. and Heegard P.M.H. (2004). Application of acute phase protein measurements in veterinary clinical chemistry. Vet. Res., 35: 163-187.

Pradeep M. (2014). Application of acute phase proteins as biomarkers in modern veterinary practice. Ind. J. Vet. Anim. Sci. Res., 43: 1-13.

Rath N.C., Anthony N.B., Kannan L., Huff W.E., Huff G.R., Chapman H.D., Erf G.F. and Wakenell P. (2009). Serum ovotransferrin as a biomarker of inflammatory diseases in chickens. Poult. Sci., 88: 2069-2074.

Rath N.C., Xie H., Huff W.E. and Huff G.R. (2008). Avian acute phase protein ovotransferrin modulates phagocyte function. In: New immunology research development, Muller G.V. (eds), Nova Science Publishers, New York, NY, USA, pp. 95-108.

Röcken C. and Shakespeare A. (2002). Pathology, diagnosis and pathogenesis of AA amyloidosis. Virchows Archiv, 440: 111-122.

Ruoslahti E. and Reed J.C. (1994). Anchorage dependence, integrins, and apoptosis. Cell 77: 477-478.

Saini P.K. and Webert D.W. (1991). Application of acute phase reactants during antemortem and postmortem meat inspection. J. Am. Vet. Med. Assoc., 198: 1898-1901.

Salamano, G., Mellia E., Tarantola M., Gennero M.S., Doglione L. and Schiavone A. (2010). Acute phase proteins and heterophil: lymphocyte ratio in laying hens in different housing systems. Vet. Rec., 167: 749-751.

Schou T.W., Permin A., Christensen J.P., Cu H.P. and Juul-Madsen H.R. (2010). Mannanbinding lectin (MBL) in two chicken breeds and the correlation with experimental Pasteurella multocida infection. Comp. Immunol. Microbiol. Infect. Dis., 33: 183-195.

Shivaprasad H.L. (1997). Pullorum disease and fowl typhoid. In: Diseases of poultry, $10^{\text {th }}$ edn. Iowa State University Press, USA. PP. 82-95.

Skaar E.P. (2010). The battle for iron between bacterial pathogens and their vertebrate hosts. PLoS Pathog., 6: e1000949. doi: 10.1371/journal.ppat.1000949.

Sohail M.U., Ijaz A., Yousaf M.S., Ashraf K., Zaneb H., Aleem M. and Rehman $\mathrm{H}$. (2010). Alleviation of cyclic heat stress in broilers by dietary supplementation of mannan-oligosaccharide and Lactobacillus-based probiotic: dynamics of cortisol, thyroid hormones, cholesterol, C-reactive protein, and humoral immunity. Poult. Sci., 89: 1934-1938.

Song Z., Zhu L., Zhao T., Jiao H. and Lin H. (2009). Effect of copper on plasma ceruloplasmin and antioxidant ability in broiler chickens challenged by lipopolysaccharide. Asian-Austral. J. Anim. Sci., 22: 1400-1406.

Sordillo L.M., Contreras G.A. and Aitken S.L. (2009). Metabolic factors affecting the 
inflammatory response of periparturient dairy cows. Anim. Health Res. Rev., 10: 53-63.

Stred S.E., Cote D., Weinstock R.S. and Messina J.L. (2003). Regulation of hemopexin transcription by calcium ionophores and phorbol ester in hepatoma cells. Mol. Cell. Endocrinol., 204: 111-116.

Superti F., Ammendolia M.G., Berlutti F. and Valenti P. (2007). Ovotransferrin. In: Bioactive Egg Compounds, Huopalahti R., Lo'pez-Fandiño R., Antonand M. and Schade R. (eds), Springer-Verlag, Berlin and Heidelberg, Germany, pp. 43-50.

Sylte M.J. and Suarez D.L. (2012). Vaccination and acute phase mediator production in chickens challenged with low pathogenic avian influenza virus; novel markers for vaccine efficacy Vaccine 30:3097-3105.

Takahashi K., Miyake N., Ohta T., Akiba Y. and Tamura K. (1998). Changes in plasma $\alpha 1-$ acid glycoprotein concentration and selected immune response in broiler chickens injected with Escherichia coli lipopolysaccharide. Br. Poult. Sci., 39: 152-155.

Takahashi K., Takagi K. and Akiba Y. (2009). Effects of dietary glycine supplementation and fish meal on inflammatory responses in broiler chicks. Brit. Poult. Sci., 50: 479486.

Thiel S., Holmskov U., Hviid L., Laursen S.B. and Jensenius J.C. (1992). The concentration of the C-type lectin, mannan-binding protein, in human plasma increases during an acute phase response. Clin. Exp. Immunol., 90: 31-35.

Tikhonov S. and Miftakhutdinov A. (2014). Diagnostics of hens stresses in poultry industry. Glob. Vet., 12: 750-755.

Tohjo H., Miyoshi F., Uchida E., Niiyama M., Syuto B., Moritsu Y., Ichikawa S. and Takeuchi M. (1995). Polyacrylamide gel electrophoretic patterns of chicken serum in acute inflammation induced by intramuscular injection of turpentine. Poult. Sci., 74: 648-655.

Tolosano E., Fagoonee S., Morello N., Vinchi F. and Fiorito V. (2010). Heme scavenging and the other facets of hemopexin. Antioxid. Red. Signal., 12: 305-320.

Tothova C., Nagy O. and Kovac G. (2014). Acute phase proteins and their use in the diagnosis of diseases in ruminants: a review. Vet. Med., 59: 163-180.
Uhlar C.M., Burgess C.J., Sharp P.M. and Whitehead A.S. (1994). Evolution of the serum amyloid A (SAA) protein superfamily. Genomics, 19: 228-235.

Upragarin N. (2005). In vitro studies on the pathogenesis of AA amyloid arthropathy in chicken. Ph. D. thesis, Utrecht University, The Netherlands.

Valenti P., Visca P., Antonini G. and Orsi N. (1985). Antifungal activity of ovotransferrin towards genus Candida. Mycopathol., 89: 169-175.

Van Miert A.S. (1995). Pro-inflammatory cytokines in a ruminant model: pathophysiological, pharmacological and therapeutic aspects. Vet. Q., 17: 41-50.

Virden W.S. and Kidd M.T. (2009). Physiological stress in broilers: ramifications on nutrient digestibility and responses. J. Appl. Poult. Res., 18: 338347.

Wagener F.A., Eggernt A., Boerman O.C., Oyen W.J., Verhofstad A., Abraham N.G., Adema G., van Kooyk Y., de Witte T. and Figdor C.G. (2001). Heme is a potent inducer of inflammation in mice and is connected by heme oxygenase. Blood, 98 : 1802-1811.

Weber A., Weber A.T., McDonald T.L. and Larson M.A. (2006). Staphylococcus aureus lipotechoic acid induces differential expression of bovine serum amyloid A3 (SAA3) by mammary epithelial cells: implications of early diagnosis of mastitis. Vet. Immunol. Immunopathol., 109: 79-83.

Xie H., Huff G.R., Huff W.E., Balog J.M., Holt P. and Rath N.C. (2002a). Identification of ovotransferrin as an acute phase protein in chickens. Poult. Sci., 81: 112-120.

Xie H., Huff G.R., Huff W.E., Balog J.M. and Rath N.C. (2003). Effects of ovotransferrin on chicken macrophages and heterophilgranulocytes. Dev. Comp. Immunol., 26: 805-815.

Xie H., Newberry L., Clark F.D., Huff W.E., Huff G.R., Balog J.M. and Rath N.C. (2002b). Changes in serum ovotransferrin levels in chickens with experimentally induced inflammation and diseases. Avian Dis., 46: 122-131.

Xie H., Rath N.C., Huff G.R., Huff W.E. and Balog J.M. (2000). Effects of Salmonella typhimurium lipopolysaccharide on broiler chickens. Poult. Sci., 79: 33-40. 
Yang F.M., Haile D.J., Berger F.G., Herbert D.C., van Beveren E. and Ghio A.J. (2003). Haptoglobin reduces lung injury associated with exposure to blood. Am. J. Physiol. Lung Cell Mol. Physiol., 284: 402-409.
Zulkifli I., Najafi P., Nurfarahin A.J., Soleimani A.F., Kumari S., Aryani A.A., O'Reilly E.L. and Eckersall P.D. (2014). Acute phase proteins, interleukin 6 , and heat shock protein 70 in broiler chickens administered with corticosterone. Poult. Sci., 93: 3112-3118.

\section{إستخدام بروتينات المرحلة الحادة كمؤشرات حيوية في الدواجن: مقال مرجعي

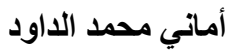 \\ جامعة الطقيلة التقتية ـ قسم العلوم الحياتية التطبيقية ـ كلية العلوم ـ الطقيلة ـ المملكة الأردنية الهاثمية}

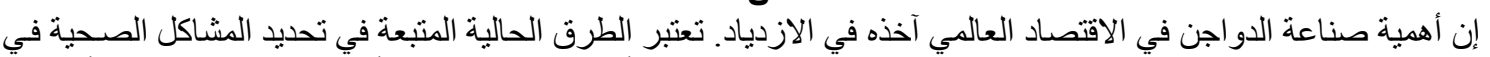

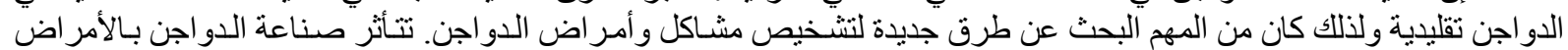

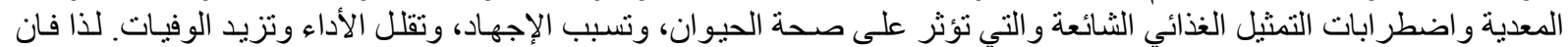

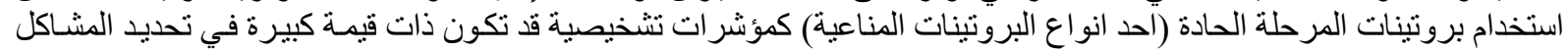

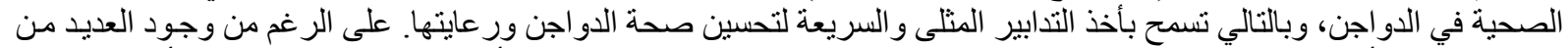

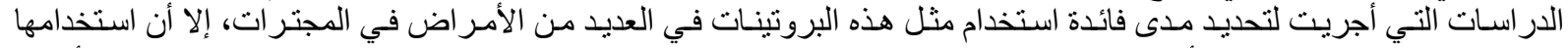

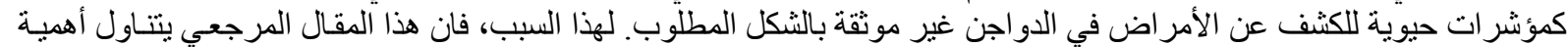

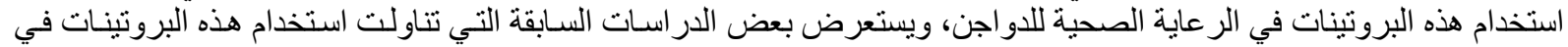

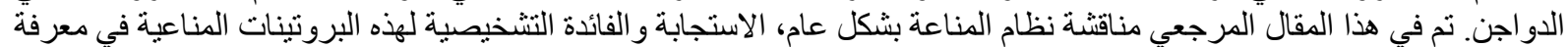

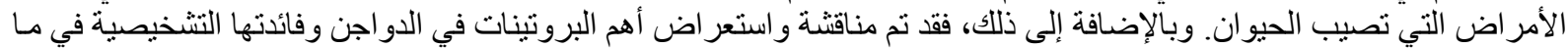

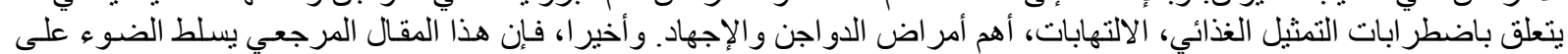

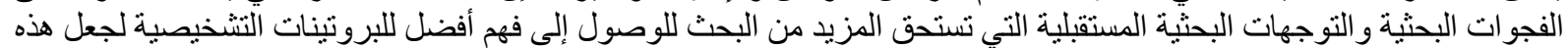

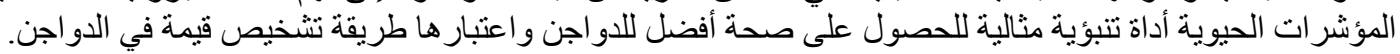

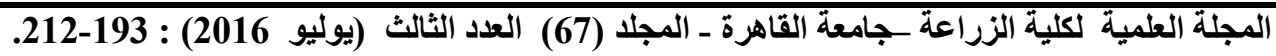

